\title{
Guidance-Cue Control of Horizontal Cell Morphology, Lamination, and Synapse Formation in the Mammalian Outer Retina
}

\author{
Ryota L. Matsuoka, ${ }^{1,2}$ Zheng Jiang, ${ }_{1}^{1}$ Ivy S. Samuels, ${ }^{3,4}$ Kim T. Nguyen-Ba-Charvet, ${ }^{5,6,7}$ Lu 0. Sun, ${ }^{1,2}$ Neal S. Peachey, ${ }^{3,4,8}$ \\ Alain Chédotal, ${ }^{5,6,7}$ King-Wai Yau, ${ }^{1}$ and Alex L. Kolodkin ${ }^{1,2}$ \\ ${ }^{1}$ The Solomon H. Snyder Department of Neuroscience, The Johns Hopkins University School of Medicine, Baltimore, Maryland 21205, ${ }^{2}$ Howard Hughes \\ Medical Institute, ${ }^{3}$ Cole Eye Institute, Cleveland Clinic Foundation, Cleveland, Ohio 44195, ${ }^{4}$ Research Service, Cleveland VA Medical Center, Cleveland, Ohio \\ 44106, ${ }^{5}$ Institut National de la Santé et de la Recherche Médicale, UMR S968, Institut de la Vision, F-75012 Paris, France, ${ }^{6}$ Université Pierre et Marie Curie \\ Paris VI, UMR S968, and ${ }^{7}$ CNRS UMR 7210, Institut de la Vision, F-75012 Paris, France, and ${ }^{8}$ Department of Ophthalmology, Cleveland Clinic Lerner \\ College of Medicine of Case Western Reserve University, Cleveland, Ohio 44195
}

In the vertebrate retina, neuronal circuitry required for visual perception is organized within specific laminae. Photoreceptors convey external visual information to bipolar and horizontal cells at triad ribbon synapses established within the outer plexiform layer (OPL), initiating retinal visual processing. However, the molecular mechanisms that organize these three classes of neuronal processes within the OPL, thereby ensuring appropriate ribbon synapse formation, remain largely unknown. Here we show that mice with null mutations in Sema6A or PlexinA4 (PlexA4) exhibit a pronounced defect in OPL stratification of horizontal cell axons without any apparent deficits in bipolar cell dendrite or photoreceptor axon targeting. Furthermore, these mutant horizontal cells exhibit aberrant dendritic arborization and reduced dendritic self-avoidance within the OPL. Ultrastructural analysis shows that the horizontal cell contribution to rod ribbon synapse formation in PlexA4 ${ }^{-I-}$ retinas is disrupted. These findings define molecular components required for outer retina lamination and ribbon synapse formation.

\section{Introduction}

Distinct neuronal cell types establish synaptic connections within two discrete synaptic regions in the vertebrate retina, the outer plexiform layer (OPL) and inner plexiform layer (IPL) (Masland, 2001; Wässle, 2004). Photoreceptors, and bipolar and horizontal cells elaborate neurites and establish the OPL during development, allowing photoreceptors to transfer visual information to bipolar and horizontal cells at the triad ribbon synapse (Wässle, 2004; Mumm et al., 2005). Horizontal cells are laterally interconnected interneurons that receive input from, and synapse onto,

Received Jan. 18, 2012; revised March 12, 2012; accepted March 27, 2012.

Author contributions: R.L.M., A.C., and A.L.K. designed research; R.L.M., Z.J., I.S.S., K.T.N.-B.-C., and L.O.S. performed research; R.L.M., Z.J., I.S.S., K.T.N.-B.-C., N.S.P., K.-W.Y., and A.L.K. analyzed data; R.L.M. and A.L.K. wrote the paper.

This work was supported by NIH Grants R01 NS35165 to A.L.K. and EY06837 to K.-W.Y; a predoctoral Fellowship from the Nakajima Foundation to R.L.M.; the Veterans Administration to I.S.S. and N.S.P.; the Foundation Fighting Blindness to N.S.P; the Fondation pour la Recherche Médicale (Programme équipe FRM) to A.C.; the Fondation Retina France to K.T.N.-B.-C.A.L.K. is an investigator of the Howard Hughes Medical Institute. We thank Dr. Cheryl Craft for the cone arrestin antibody; Dr. Françoise Haeseleer for the CaBP5 antibody; and Dr. Fumikazu Suto for the PlexA2 and PlexA4 antibodies. Wearealso grateful to Drs. Martin Riccomagno and Kenji Mandai for helpful suggestions and discussions throughout this project; Dr. Michael Delannoy for help in tissue preparation and sectioning for EM analysis; Dontais Johnson for assistance with mouse experiments; and members of the Kolodkin laboratory for assistance.

Correspondence should be addressed to Alex L. Kolodkin, The Solomon H. Snyder Department of Neuroscience, Howard Hughes Medical Institute, The Johns Hopkins University School of Medicine, 725 North Wolfe Street, Baltimore, MD 21205. E-mail: kolodkin@jhmi.edu.

R. L. Matsuoka's present address: Department of Biochemistry and Biophysics, University of California, San Francisco, San Francisco, CA 94158

DOI:10.1523/JNEUROSCI.0267-12.2012

Copyright $\odot 2012$ the authors $\quad 0270-6474 / 12 / 326859-10 \$ 15.00 / 0$ rod and cone photoreceptors, providing lateral inhibitory feedback that is critical for sharpening visual images (Wässle, 2004; Mumm et al., 2005). Horizontal cells form gap junctions among themselves and also connect with rods and cones within the OPL (Wässle, 2004; Mumm et al., 2005). The molecular mechanisms that govern neurite targeting of these three cell types to the OPL, that allow for even coverage of horizontal cell processes in the OPL, and that facilitate the establishment of ribbon synapses within the OPL remain largely unknown.

Neurotransmission is important for the assembly of neuronal circuits in the OPL. Synaptic release of glutamate from photoreceptors is required for the correct stratification of horizontal cell neurites, bipolar cell dendrites, and photoreceptor axon terminals within the OPL. Mutations in genes encoding presynaptic proteins (Bassoon, CaBP4) (Dick et al., 2003; Haeseleer et al., 2004) or ion channels (Cacna1f, Cacna2d4) (Chang et al., 2006; Wycisk et al., 2006) that control the glutamate vesicle release from photoreceptor axonal terminals, or mutations that impair photoreceptor signaling and induce photoreceptor degeneration (Strettoi et al., 2002, 2003; Dick et al., 2003; Claes et al., 2004; Haeseleer et al., 2004; Specht et al., 2007), result in ectopic neurite outgrowth into the outer nuclear layer (ONL) from rod photoreceptors, and bipolar and horizontal cells (Strettoi et al., 2002, 2003; Dick et al., 2003; Claes et al., 2004; Haeseleer et al., 2004; Specht et al., 2007). However, mutations affecting postsynaptic components of glutamate-mediated signal transduction onto ON bipolar cells (mGluR6, Go $\alpha$, Nyx, and Trpm1) are not asso- 
ciated with these types of deficits (Masu et al., 1995; Tagawa et al., 1999; Dhingra et al., 2000; Pinto et al., 2007). Therefore, synaptic release of glutamate from photoreceptors appears crucial for constraining retinal neurites within the OPL. Afferent inputs from photoreceptors also regulate horizontal cell morphology, including dendritic field size and axon terminal complexity (Reese et al., 2005; Raven et al., 2007). In addition, homotypic interactions among horizontal cells control their dendritic field size (Reese et al., 2005; Huckfeldt et al., 2009), but the molecules required for these homotypic interactions are unknown.

We previously demonstrated that distinct subclasses of transmembrane semaphorins (Sema6A and Sema5A/Sema5B) are expressed in different domains and cell types of the developing murine retina, serving crucial and distinct roles in directing multiple retinal subtype-targeting events within the IPL in vivo (Matsuoka et al., 2011a,b). Here, we show that transmembrane semaphorin-plexin signaling also regulates OPL neural circuit elaboration in vivo and ensures correct formation of ribbon synapses within the OPL.

\section{Materials and Methods}

Animals. The day of birth in this study is designated as postnatal day 0 (P0). The PlexA4-null mutant mouse line and Sema6A gene-trap mutant mouse line were previously described (Leighton et al., 2001; Yaron et al., 2005). The PlexA2 ${ }^{-1-}, \mathrm{Npn-1} \mathrm{Sema-/Sema-}^{-}$and Npn$2^{-/-}$mutant mice also have been described previously (Giger et al., 2000; Gu et al., 2003; Suto et al., 2007). The age of adult mice of either sex used for this study is 2-6 months.

Immunohistochemistry. Immunohistochemistry was performed as previously described (Matsuoka et al., 2011a). The following primary antibodies were used: rabbit anti-calbindin (Swant at 1:2500); mouse anti-neurofilament ( $2 \mathrm{H} 3$ concentrated, Developmental Studies Hybridoma Bank at 1:2000); mouse anti-Go $\alpha$ (Millipore at 1:500); goat anti-mouse Sema6A (R\&D Systems at 1:200); Armenian hamster antiPlexA4 (generous gift from Dr. Fumikazu Suto, National Center of Neurology and Psychiatry, Tokyo, Japan, at 1:400) (Suto et al., 2007); guinea pig anti-vGlut1 (Millipore at 1:2000); mouse anti-CtBP2 (BD Biosciences at 1:2000); rabbit anti-PlexA2 (generous gift from Dr. Fumikazu Suto at 1:400) (Suto et al., 2007); mouse antiPSD95 (Millipore at 1:500); mouse antiGephyrin (Synaptic Systems at 1:250); guinea pig anti-vGAT (Millipore at 1:500); rabbit anti-cone arrestin (generous gift from Dr. Cheryl Craft, University of Southern California, Los Angeles, $\mathrm{CA}$, at 1:3000); mouse anti-PKC $\alpha$ (Millipore at 1:200); and rabbit anti-CaBP5 (generous gift from Dr. Françoise Haeseleer, University of Washington, Seattle, WA, at 1:200) (Haeseleer et al., 2000).
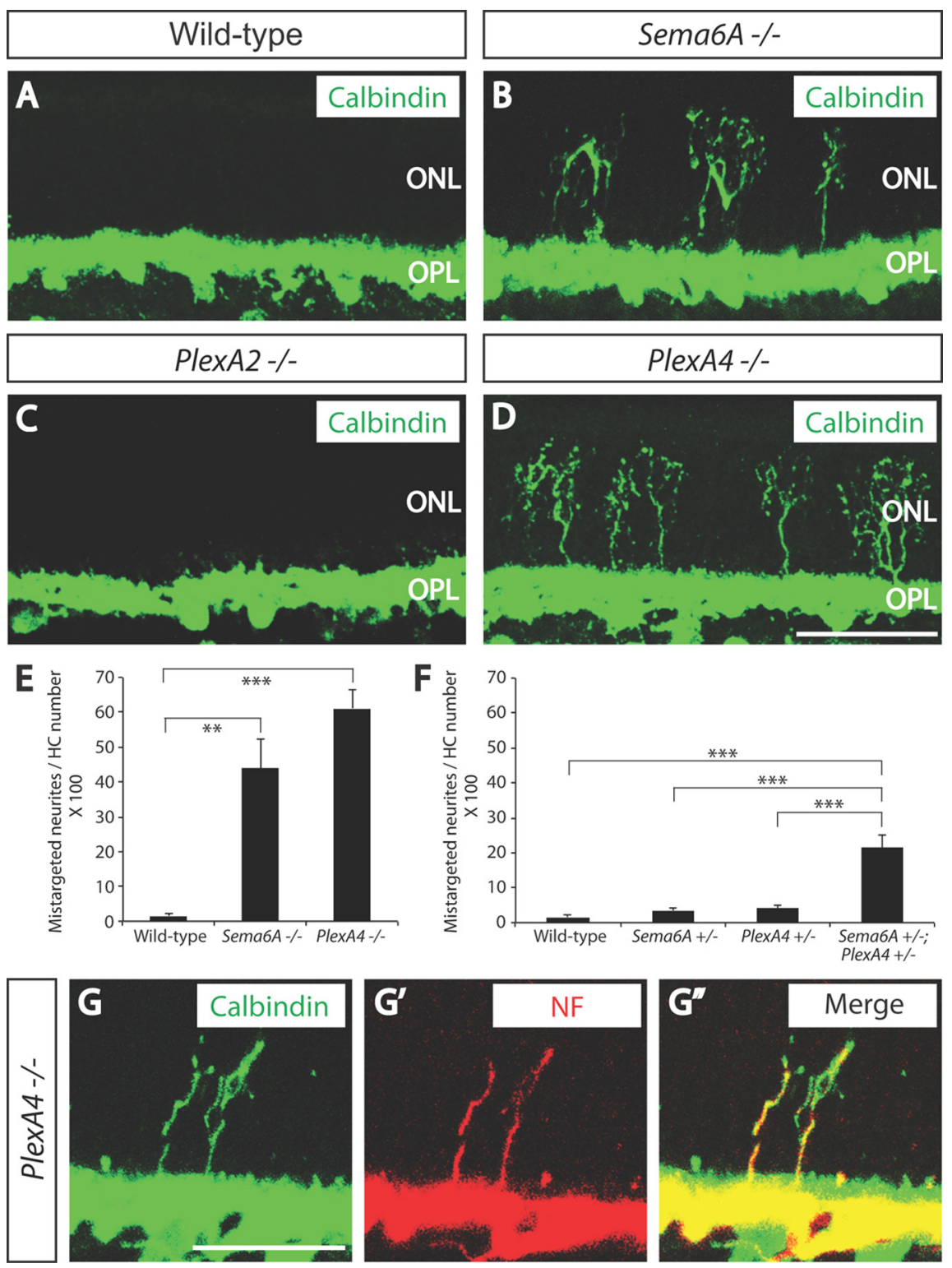

Figure 1. Sema6A and PlexinA4 direct horizontal cell axon targeting to the OPL in vivo. $\boldsymbol{A}-\boldsymbol{D}, \mathrm{WT}(\boldsymbol{A})$, Sema6 $A^{-1-}(\boldsymbol{B})$, PlexA2 ${ }^{-1-}(\boldsymbol{C})$, and PlexA4 ${ }^{-1-}(\boldsymbol{D})$ adult retina sections were immunostained with the horizontal cell marker anticalbindin (green). In WT retina $(\boldsymbol{A})$, all horizontal cell neurites stratify in the $\mathrm{OPL}$; however, in Sema6 $A^{-/-}$retinas $(\boldsymbol{B})$, horizontal cells exhibit a pronounced defect in neurite stratification in the OPL, and a significant number of horizontal cell neurites reside in the $0 \mathrm{NL}$. Horizontal cells in PlexA4 ${ }^{-1-}$ retinas (D) exhibit a similar defect in neurite stratification as observed in Sema6 $A^{-/-}$retinas. In contrast, horizontal cells in PlexA2 ${ }^{-1-}$ retinas $(\boldsymbol{C})$ do not exhibit this stratification defect. $E$, Quantification of aberrant calbindin ${ }^{+}$neurites that reside in the ONL in adult WT, Sema6 ${ }^{-\prime}$, and PlexA4 ${ }^{-\prime-}$ mice $\left(n=3\right.$ animals for PlexA4 ${ }^{-1-}$, and $n=4$ animals for WT and Sema6A ${ }^{-1-}$; presented here normalized to the number of horizontal cells quantified; $n=1072$ cells for WT, $n=1176$ cells for Sema6 $A^{-/-}$, and $n=1050$ cells for PlexA4 ${ }^{-1-}$ mice). Both Sema $6 A^{-1-}$ and PlexA4 ${ }^{-1-}$ retinas exhibit a pronounced increase in the number of aberrant horizontal cell neurites that reside in the ONL $\left(43.9 \pm 8.4 \%\right.$ for Sema6 $\mathrm{A}^{-\prime-}$ and $61.1 \pm 5.5 \%$ for PlexA4 $\left.{ }^{-\prime-}\right)$ compared with WT retinas $(1.6 \pm 0.5 \%)$. Error bars are SEM. ${ }^{* *} p<0.01,{ }^{* * *} p<0.001$, one-way ANOVA followed by Tukey's HSD multiple-comparison test. $\boldsymbol{F}$, Quantification of aberrant calbindin ${ }^{+}$neurites that reside in the ONL in adult WT, Sema6A $A^{+/-}$, PlexA4 $4^{+/-}$, and Sema6A ${ }^{+/-} ;$PlexA4 ${ }^{+/-}$mice $(n=4$ animals for each genotype; normalized to the number of horizontal cells quantified; the same WT as quantification from $\boldsymbol{E}, n=1174$ cells for Sema6 ${ }^{+/-}, n=1161$

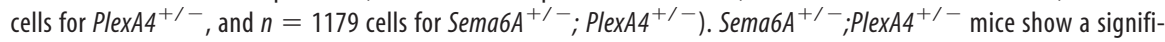
cantly increased number of aberrant horizontal cell neurites in the ONL (21.4 $\pm 3.8 \%)$ compared with the other three genotypes (1.6 $\pm 0.5 \%$ for WT, $3.5 \pm 0.7 \%$ for Sema $6 A^{+/-}$, and $4.0 \pm 1.1 \%$ for PlexA4 ${ }^{+/-}$). Error bars are SEM. ${ }^{* * *} p<$ 0.001 , one-way ANOVA followed by Tukey's HSD multiple-comparison test. $G-G^{\prime \prime}$, PlexA4 $4^{-\prime-}$ adult retinas were double immunostained with anti-calbindin $(\boldsymbol{G})$ and anti-neurofilament $\left(\mathrm{NF}, \boldsymbol{G}^{\prime}\right)$ (merged in $\boldsymbol{G}^{\prime \prime}$ ). Aberrant horizontal cell neurites localized in the $0 \mathrm{NL}$ of PlexA4 ${ }^{-\prime-}$ retinas are both calbindin and neurofilament positive, suggesting that these aberrant neurites are axonal poles of horizontal cells. Scale bars: (in $\boldsymbol{D}) \boldsymbol{A}-\boldsymbol{D}, 50 \mu \mathrm{m}$; (in $\mathbf{G}) \mathbf{G}-\boldsymbol{G}^{\prime \prime}, 30 \mu \mathrm{m}$. 
7
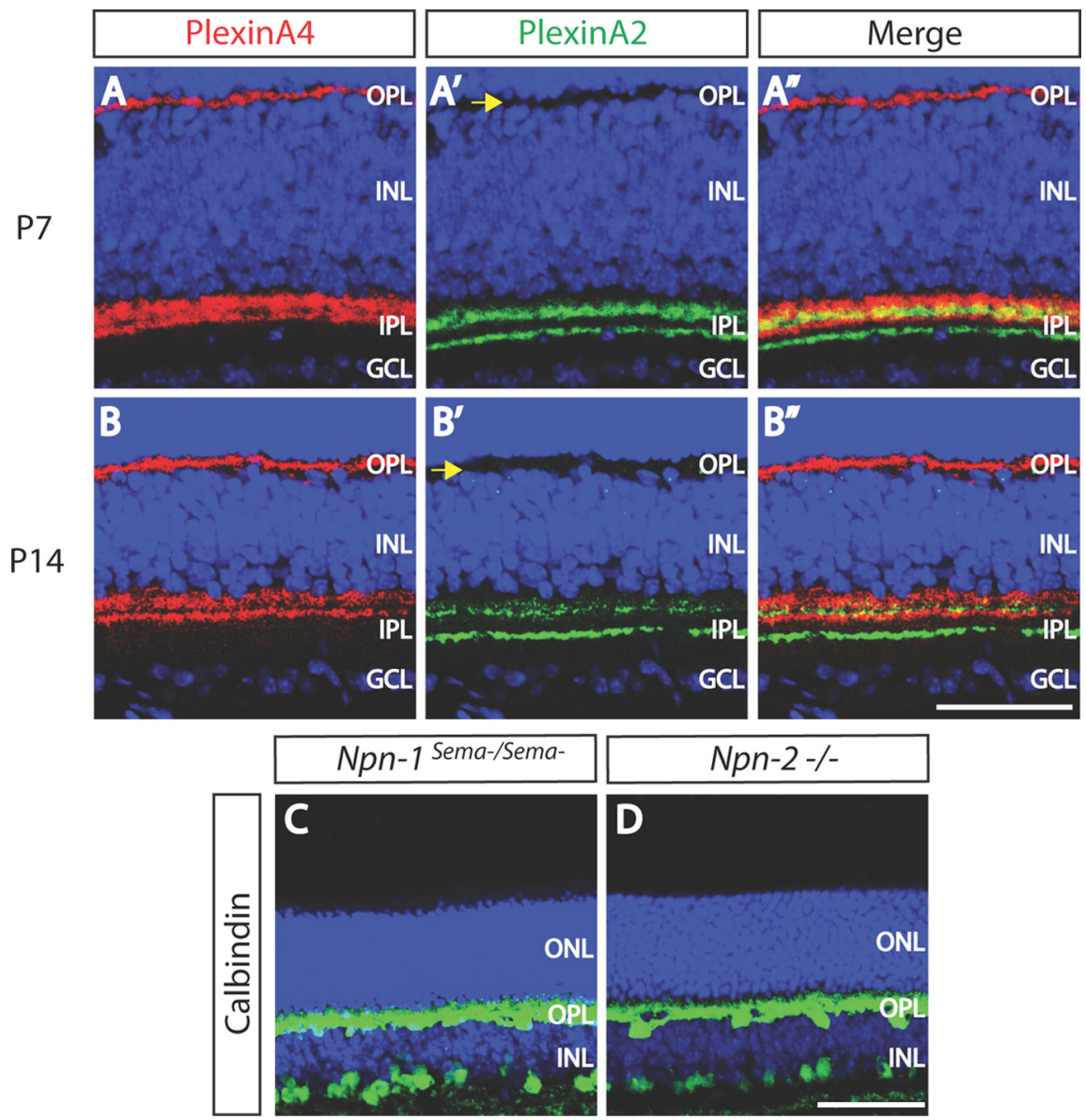

Figure 2. PlexA4 and PlexA2 protein expression in the developing OPL, and normal horizontal cell neurite stratification in neuropilin-deficient retinas. $\boldsymbol{A}-\boldsymbol{B}^{\prime \prime}$, WT retina sections from P7 $\left(\boldsymbol{A}-\boldsymbol{A}^{\prime \prime}\right)$ or P14 $\left(\boldsymbol{B}-\boldsymbol{B}^{\prime \prime}\right)$ mice were double immunostained with anti-PlexA4 ( $\boldsymbol{A}, \boldsymbol{B}$, red) and anti-PlexA2 $\left(\boldsymbol{A}^{\prime}, \boldsymbol{B}^{\prime}\right.$, green). At both P7 and P14, PlexA4 is localized in the OPL, whereas PlexA2 immunostaining is not observed in the OPL at these postnatal stages (yellow arrows). C, D, Npn $7^{\text {sema- } / \text { sema- }}(\boldsymbol{C})$ and Npn2 $2^{-/-}$ (D) adult retina sections were immunostained with anti-calbindin. Both Npn $1^{\text {sema-/sema- }}(\boldsymbol{C})$ and Npn2 $2^{-1-}(\boldsymbol{D})$ mice do not exhibit aberrant horizontal cell neurite extension into the $0 \mathrm{NL}$ ( $n=3$ animals for each genotype), suggesting that neuropilins are not required for Sema6A and PlexinA4 regulation of horizontal cell neurite stratification in vivo. Scale bars: $\boldsymbol{B}^{\prime \prime}$ (for $\left.\boldsymbol{A}-\boldsymbol{B}^{\prime \prime}\right), \boldsymbol{D}$ (for $\boldsymbol{C}$, D), $50 \mu \mathrm{m}$.

Quantification of aberrant horizontal cell neurites and genetic interaction analysis. Retinal cross sections ( $40 \mu \mathrm{m}$ thickness) from adult mice of either sex were immunostained with anti-calbindin for quantification of aberrant horizontal cell neurites. For genetic interaction analysis, retina sections from adult wild-type (WT), Plex $A 4^{+/-}, S e m a 6 A^{+/-}$, and Sema6 $A^{+/-} ;$Plex $A 4^{+/-}$mice were used for quantification $(n=4$ retinas from four animals for each genotype). The number of horizontal cell neurites, which aberrantly project to the ONL, is normalized by the number of horizontal cell bodies within the areas used for the quantification. The number of aberrant horizontal cell neurites that directly originate from the OPL were quantified, and branches of the neurites were not included in the quantification.

Density recovery profile analysis. Density recovery profile (DRP) analysis was performed as previously described (Rodieck, 1991; Rockhill et al., 2000). Confocal images of five selected regions $(298 \times 298$ $\mu \mathrm{m}$ field) from each whole-mount retina $(n=3$ retinas from three animals of either sex for WT and PlexA4 ${ }^{-1-}$ genotypes) were used to measure the DRP of horizontal cells. The regions we used for this analysis did not include the areas near peripheral edges or optic nerve heads of retinas.

Horizontal cell dye injection. Eyes were enucleated from anesthetized mice. After retinas were isolated, they were incubated in oxygenated Ames medium with $10 \mu \mathrm{M}$ DAPI at $35^{\circ} \mathrm{C}$ for $11 \mathrm{~min}$. These retinas were cut into four pieces and flattened on black filter papers. Dye injection into horizontal cells was performed at $23^{\circ} \mathrm{C}$ with continuous perfusion of oxygenated Ames medium, running at $5 \mathrm{ml} / \mathrm{min}$. Electrodes were pulled from borosilicate glass capillary by a P-1000 micropipette puller. The electrode was tip filled with $8 \mathrm{~mm}$ Alexa Fluor hydrazide 555 (Invitrogen) and 0.5\% Lucifer yellow dissolved in $\mathrm{dd}_{2} \mathrm{O}$, and backfilled with $3 \mathrm{M} \mathrm{KCl}$. The electrode resistance was $100 \sim 180$ $\mathrm{M} \Omega$, and the dye solution was injected by biphasic current ( $\pm 1 \mathrm{nA}, 2 \mathrm{~Hz}, 3 \mathrm{~min}$ ). Horizontal cells were identified by their large, flat DAPI-labeled nuclei situated close to the outer plexiform layer. After the dye injection, retinas were fixed in 4\% paraformaldehyde for $15 \mathrm{~min}$ at room temperature. The retinas were washed in PBS for $45 \mathrm{~min}$, and images were taken using a Zeiss confocal microscope (LSM-510). The dendrites of the horizontal cells filled with dye was drawn semi-manually in NeuroStudio (Wearne et al., 2005). The number of crossings among dendrites was manually counted, and the neurite length was measured automatically by the NeuroStudio software.

Transmission electron microscopy. Eyes were enucleated from anesthetized 4- to 6-monthold adult mice of either sex $(n=3$ animals for WT and PlexA4 $4^{-/-}$genotypes). Retina cups were isolated and fixed in 3\% paraformaldehyde $1.5 \%$ glutaraldehyde in $0.1 \mathrm{M} \mathrm{Ca-}$ cacodylate, $3 \mathrm{~mm} \mathrm{CaCl}_{2}$, and $2.5 \%$ sucrose at $\mathrm{pH} 7.4$ at $4^{\circ} \mathrm{C}$ overnight. Each of the fixed retina cups was cut into three to four pieces; washed three times for $15 \mathrm{~min}$ in $0.1 \mathrm{M} \mathrm{Ca-}$ cacodylate, $3 \mathrm{~mm} \mathrm{CaCl}_{2}$, and $2.5 \%$ sucrose at $\mathrm{pH} 7.4$; and fixed in $1.0 \% \mathrm{OsO} 4$ on ice for $1 \mathrm{~h}$. The retina tissues were then incubated in $1.0 \%$ Kellenberger's uranyl acetate, dehydrated in graded series of ethanol, infiltrated, and flat embedded in EPON. Ultrathin (80 $\mathrm{nm}$ ) sections were cut with a Reichert Ultracut E microtome using a Diatome diamond knife. Images were taken using a Hitachi H-7600 transmission electron microscope. For classification of surrounded and nonsurrounded rod ribbon synapses, we categorized each rod ribbon synapse into two groups: when a rod ribbon is surrounded by two components of horizontal cell neurite tips, we define it as a surrounded rod ribbon; when a rod ribbon is not surrounded by two components of horizontal cell neurite tips, we define it as a nonsurrounded rod ribbon. The total number of rod ribbon synapses quantified for this analysis was 233 for WT retinas and 234 for PlexA4 ${ }^{-1-}$ retinas.

Electroretinogram recording. Electroretinogram (ERG) measurements were performed as previously described (Budzynski et al., 2010). The amplitude of the a-wave was measured at $8 \mathrm{~ms}$ after flash presentation from the prestimulus baseline. The amplitude of the b-wave was measured to the b-wave peak from the a-wave trough or, if no a-wave was present, from the baseline.

Statistical analysis. The statistical significance of the differences between mean values among two or more groups was determined using Student's $t$ test or ANOVA followed by Tukey's HSD test, respectively. The criterion for statistical significance was set at $p<0.05$. Error bars are SEM.

\section{Results}

Sema6A-PlexA4 signaling directs horizontal cell axon targeting to the $\mathrm{OPL}$

To assess transmembrane-semaphorin function in the murine OPL during development, we first analyzed retinas from adult 

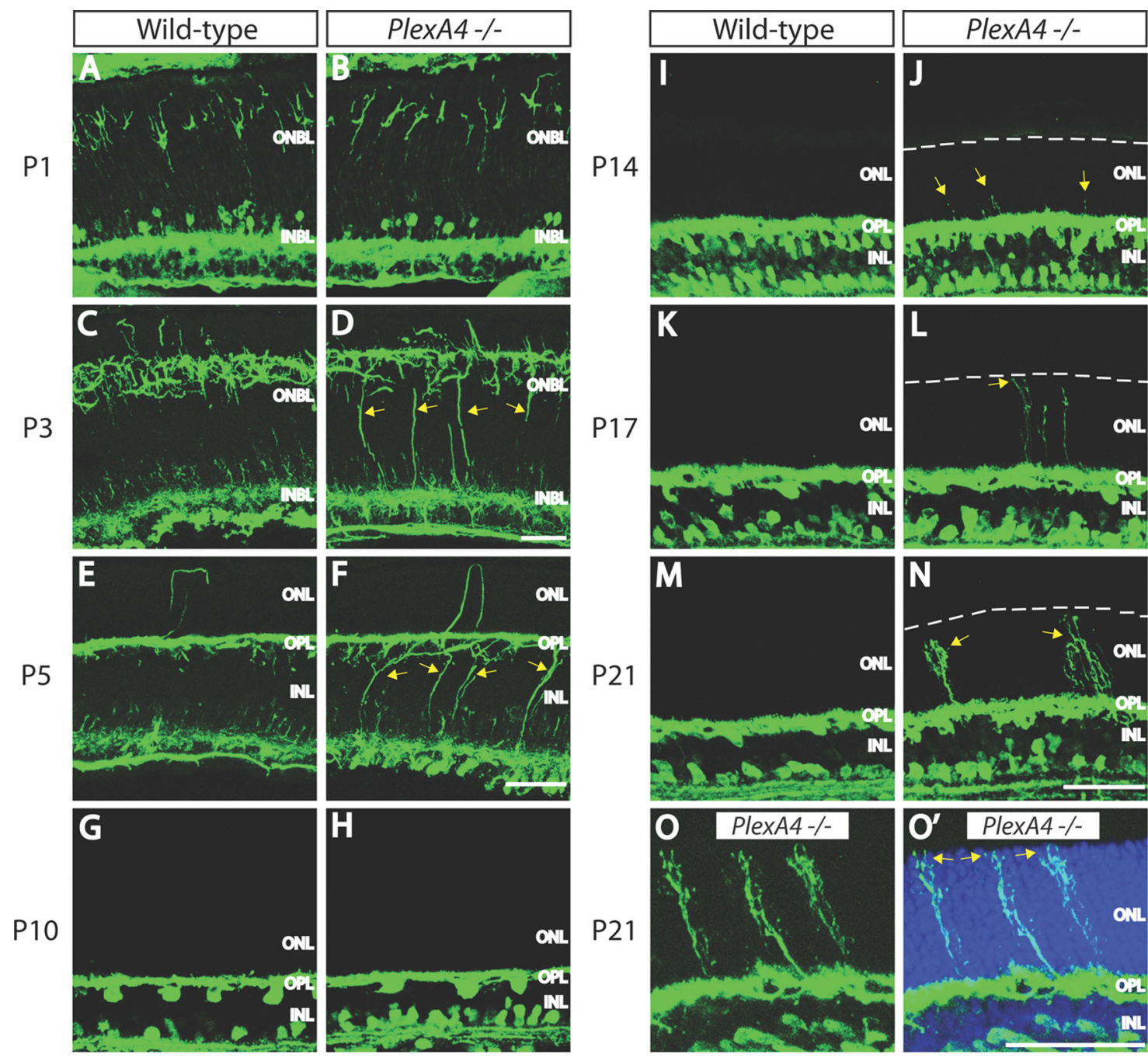

\section{(1)}
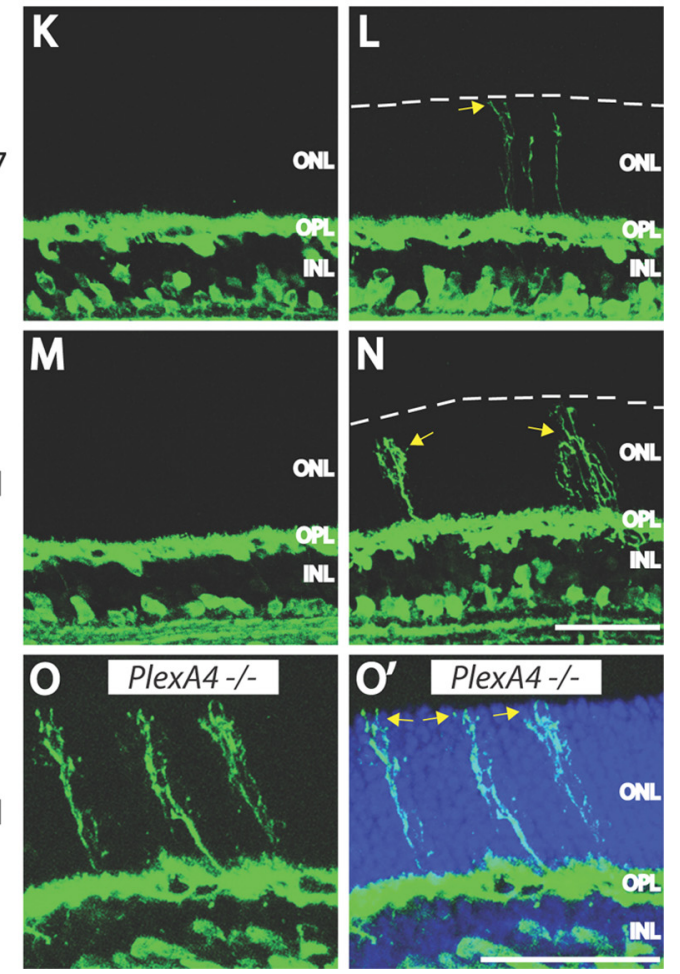

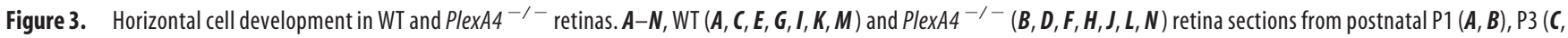
D), P5 $(\boldsymbol{E}, \boldsymbol{F})$, P10 $(\boldsymbol{G}, \boldsymbol{H})$, P14 $(\boldsymbol{I}, \boldsymbol{J})$, P17 $(\boldsymbol{K}, \boldsymbol{L})$, and P21 $(\boldsymbol{M}, \boldsymbol{N})$ mice were immunostained with anti-neurofilament $(\boldsymbol{A}-\boldsymbol{F})$ or anti-calbindin $(\boldsymbol{G}-\boldsymbol{N})$. In PlexA4 ${ }^{-/-}$retinas, aberrant horizontal cell neurites directed toward the ONL are observed as early as P14 (yellow arrows) and then more clearly at later time points. White dashed lines indicate the edge of the outermost ONL $(\boldsymbol{J}, \boldsymbol{L}, \boldsymbol{N})$. Horizontal cells in PlexA4 ${ }^{-1-}$ retinas do not show correct neurite stratification within the OPL (yellow arrows) at P3 (D) and P5 $(\boldsymbol{F})$ compared with WT retinas; however, the ectopic horizontal cell neurites across the INL of PlexA4 ${ }^{-1-}$ retinas stratify within the OPL by P10 $(\boldsymbol{H})$. At P14, horizontal cells in PlexA4 ${ }^{-/-}$retinas begin extending aberrant neurites toward the ONL ( $\boldsymbol{J}$, yellow arrows), and these aberrant neurites extend to the outermost photoreceptor cell body layers by P17 (L). Axon terminal-like structures are observed in the ONL in PlexA4 ${ }^{-\prime-}$ retinas at P21 ( $\boldsymbol{N}$, yellow arrows). $\mathbf{0}, \mathbf{O}^{\prime}$, High magnification of P21 PlexA4 ${ }^{-/-}$retina section immunostained with anti-calbindin $(\mathbf{0})$ and

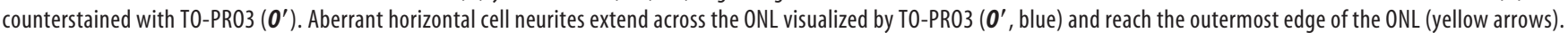
Scale bars: $\boldsymbol{F}$ (for $\boldsymbol{A}-\boldsymbol{F}), \boldsymbol{N}($ for $\boldsymbol{G}-\boldsymbol{N}), \boldsymbol{O}^{\prime}$ (for $\left.\mathbf{0}, \boldsymbol{O}^{\prime}\right), 50 \mu \mathrm{m}$.

mice harboring null alleles in Sema6A $\left(\right.$ Sema6 $\left.^{-/-}\right)$(Leighton et al., 2001), Sema6B (Sema6B ${ }^{-1-}$ ) (Tawarayama et al., 2010), or both Sema6C and Sema6D (Sema6C ${ }^{-1-}$;Sema6 ${ }^{-1-}$ ) (Leslie et al., 2011) using immunohistochemistry. We used antibodies against calbindin, $\mathrm{PKC} \alpha$, Go $\alpha$, and vGlut1, which label horizontal cells, rod bipolar cells, ON bipolar cells, and photoreceptor axonal terminals, respectively. We observed a defect in horizontal cell neurite stratification in adult Sema6 $A^{-\prime-}$ mice; many neurites, instead of being confined within the OPL (Fig. 1A), strayed ectopically into the ONL (Fig. $1 B$ ). Sema6A serves as a ligand for the PlexA2 or PlexA4 receptors during development of the cerebellum, the hippocampus, and the spinal cord in vivo (Suto et al., 2007; Renaud et al., 2008; Rünker et al., 2008). We found that adult $P$ PlexA4 ${ }^{-\prime-}$, but not PlexA2 ${ }^{-\prime-}$, mutant retinas phenocopy Sema6 $A^{-1-}$ retinas (Fig. $1 C, D)$. PlexA4, but not PlexA2, is expressed within the OPL of the developing postnatal retina (Fig. $2 A-B^{\prime \prime}$ ). Neuropilin-deficient retinas (Npn-1 Sema-/Sema- $^{\text {(Gu et al., 2003) or Npn-2 }}{ }^{-/-}$(Giger et al.,
2000)) did not show the defects in horizontal cell neurite stratification observed in Sema6A $A^{-1-}$ or PlexA4 ${ }^{-1-}$ retinas (Fig. $2 C, D$ ), showing that neuropilins do not serve as obligate coreceptors with PlexA4 for regulating horizontal cell neurite stratification. The horizontal cell neurite-targeting defect in Sema6A $\mathrm{A}^{-/-}$and PlexA4 ${ }^{-/-}$ retinas is fully penetrant, although some variation in expressivity was observed among mutant animals, with Sema $6 \mathrm{~A}^{-1-}$ retinas tending to display a somewhat less severe phenotype than $\mathrm{PlexA} 4^{-\prime-}$ retinas ( $n=10$ adult animals for each genotype) (Fig. $1 E$ ). However, double-homozygous Sema6A ${ }^{-1-}$;PlexA4 ${ }^{-1-}$ mutants exhibited a similar severity of this horizontal cell neurite stratification defect as we observed in PlexA4 ${ }^{-1-}$ retinas (data not shown). In addition, we found that Sema6A and PlexA4 mutants show strong genetic interactions with respect to aberrant horizontal cell neurite stratification in the outer retina in vivo $\left(\right.$ Sema6A ${ }^{+/-} ; P_{\text {PlexA4 }}{ }^{+/-}$transheterozygous mutants) (Fig. $1 F$ ). These results show that Sema6A and PlexA4 together constrain horizontal cell neurite stratification to the 

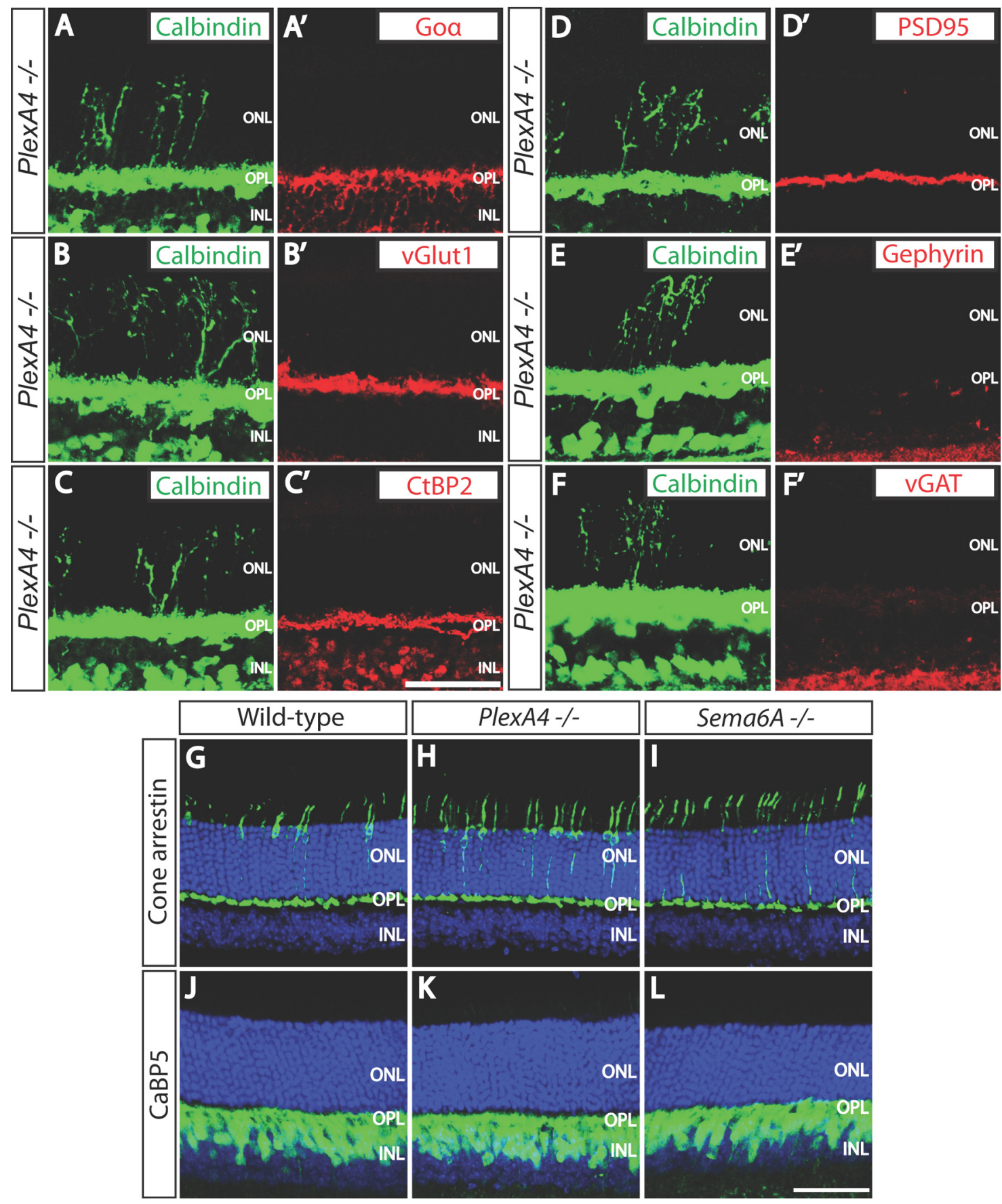

Figure 4. Aberrant horizontal cell neurites are not associated with $\mathrm{ON}$ bipolar cell dendrites, photoreceptor axon terminals, ribbon synapses, or excitatory or inhibitory synaptic markers in PlexA4 ${ }^{-1-}$ retinas. $\boldsymbol{A}-\boldsymbol{F}^{\prime}$, PlexA4 ${ }^{-\prime-}$ adult retina sections were double immunostained with anti-calbindin $(\boldsymbol{A}-\boldsymbol{E}, \boldsymbol{F})$, and anti-Go $\alpha\left(\boldsymbol{A}^{\prime}\right)$, anti-vGlut1 $\left(\boldsymbol{B}^{\prime}\right)$, anti-C-terminal binding protein 2 (CtBP2, a ribbon synapse marker, $\left.\boldsymbol{C}^{\prime}\right)$, anti-PSD95 $\left(\boldsymbol{D}^{\prime}\right)$, anti-Gephyrin $\left(\boldsymbol{E}^{\prime}\right)$, or anti-vGAT $\left(\boldsymbol{F}^{\prime}\right)$. Ectopic horizontal cell neurites located in the 0NL of PlexA4 ${ }^{-\prime-}$ adult retinas are not accompanied by $0 \mathrm{~N}$ bipolar cell dendrites $\left(\boldsymbol{A}, \boldsymbol{A}^{\prime}\right)$ or photoreceptor axon terminals $\left(\boldsymbol{B}, \boldsymbol{B}^{\prime}\right)$, and therefore ribbon synapses are not formed on the aberrant horizontal cell neurites in the ONL $\left(\boldsymbol{C}, \boldsymbol{C}^{\prime}\right)$. Ectopic horizontal cell neurites located in the $0 \mathrm{NL}$ of PlexA $4^{-/-}$adult retinas are also not associated with excitatory postsynaptic regions $\left(\boldsymbol{D}, \boldsymbol{D}^{\prime}\right)$, inhibitory

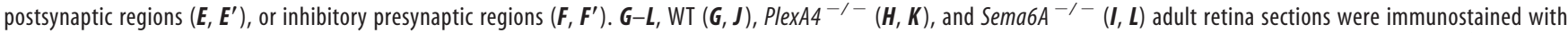
anti-cone arrestin $(\mathbf{G}-\boldsymbol{I})$ or anti-calcium binding protein $5(\mathrm{CaBP5}, \boldsymbol{J}-\boldsymbol{L})$. Cone photoreceptor axonal targeting to the OPL does not apparently differ among WT $(\mathbf{G})$, PlexA4 ${ }^{-\prime-}(\boldsymbol{H})$, and Sema6 $A^{-1-}(\boldsymbol{I})$ retinas. Rod bipolar cell as well as type 3 and type 5 cone bipolar cell dendrites do not exhibit aberrant neurite extension into the 0NL of PlexA4 ${ }^{-/-}(\boldsymbol{K})$ and Sema6 $A^{-\prime-}(\boldsymbol{L})$. Scale bars: $\boldsymbol{C}^{\prime}$ (for $\left.\boldsymbol{A}-\boldsymbol{F}^{\prime}\right), \boldsymbol{L}$ (for $\left.\mathbf{G}-\boldsymbol{L}\right), 50 \mu \mathrm{m}$.

OPL. The aberrant neurites in adult Sema6 $A^{-1-}$ and PlexA4 ${ }^{-1-}$ retinas are immunopositive for neurofilament (Fig. $1 G-G^{\prime \prime}$; data not shown), suggesting that they are horizontal cell axons (Peichl and González-Soriano, 1994; Haverkamp and Wässle, 2000; Lee et al., 2008), which in the mouse retina contact rods (Peichl and GonzálezSoriano, 1993, 1994).
Sema6A-PlexA4 signaling regulates horizontal cell morphological remodeling during postnatal development We next determined when during neural development these defects are observable. At P1, horizontal cell soma location and morphology are similar in PlexA4${ }^{-/-}$and $\mathrm{WT}$ retinas (Fig. $3 A, B)$. Between P1 and P5, WT horizontal cells gradually retract 
vertically oriented neurites and extend their lateral dendritic arbors into the future OPL (Huckfeldt et al., 2009), remaining in the OPL into adulthood. At P3 and $\mathrm{P} 5$ in PlexA4${ }^{-/-}$retinas, however, a significant number of vertically oriented basal, but not apical, horizontal cell neurites remain (Fig. $3 C-F$ ). By $\mathrm{P} 10$, the ectopic horizontal cell vertical neurites in the PlexA $4^{-/-}$retina have disappeared, leaving overall neurite stratification apparently similar to WT (Fig. $3 G, H$ ). P14 is the developmental stage when horizontal cell neurites normally invade photoreceptor presynaptic terminals to ultimately form ribbon synapses (Blanks et al., 1974). It is at this stage when we observe that horizontal cells in PlexA4 ${ }^{-/-}$retinas again extend aberrant neurites toward the ONL (Fig. 3I,J), extending almost completely through the ONL by P17 (Fig. $3 K, L)$. By P21, the vertically extended neurites exhibit elaborate axon terminallike structures in the ONL (Fig. 3M-O' ). Thus, PlexA4 regulates the reorganization of horizontal cell neurites during early, and again during later, postnatal retinal development. Sema6 $A^{-1-}$ retinas phenocopy these PlexA $4^{-/-}$horizontal cell neurite-targeting defects (data not shown). Ectopic outgrowth of horizontal cell neurites into the ONL observed in Sema6A $A^{-1-}$ and PlexA4 $4^{-1-}$ retinas is not, therefore, due to neurite sprouting that is observed in the outer retina of aged mice (Liets et al., 2006; Samuel et al., 2011).

\section{Aberrant horizontal cell neurites are not accompanied by aberrant bipolar cell subtype neurites, photoreceptor neurites, or ribbon synapse markers} Ectopic horizontal cell neurites that come to reside in the ONL of PlexA4 $4^{-1-}$ and Sema6 $A^{-1-}$ retinas are not associated with markers of photoreceptor axon terminals, bipolar cell dendrites, or ribbon synapses (Fig. 4; data not shown). This is in contrast to what is observed in mouse lines harboring mutations in genes encoding the synaptic proteins Bassoon, CaBP4, Cacnalf, and Cacna2d4; in these mutants, retinal stratification deficits involve all of the three OPL neuronal cell types that contribute to the ribbon synapse: horizon-

tal cells, bipolar cells, and photoreceptor axon terminals (Strettoi et al., 2002, 2003; Dick et al., 2003; Claes et al., 2004; Haeseleer et al., 2004; Specht et al., 2007). Thus, Sema6A/PlexA4 signaling regulates horizontal cell neurite stratification through a mechanism distinct from that used by these synaptic proteins, which are essential for glutamate neurotransmission.

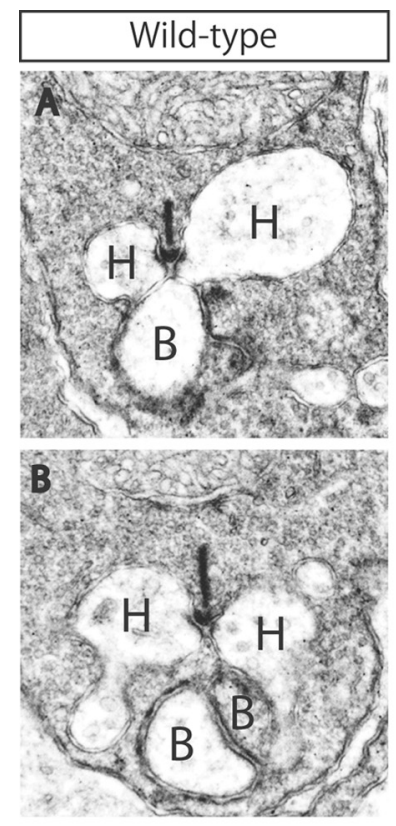

F
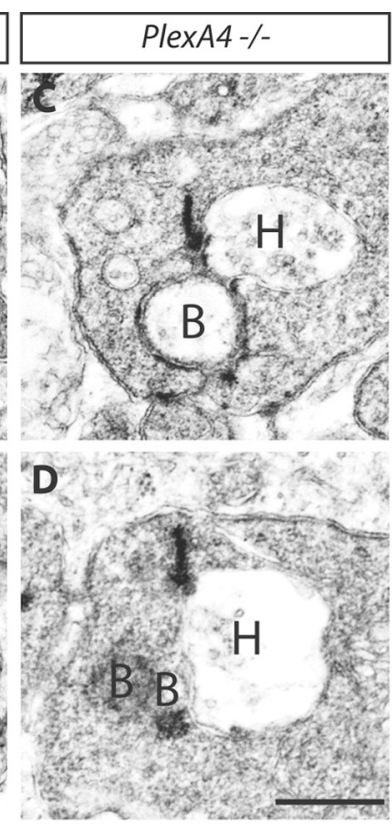

G 1000

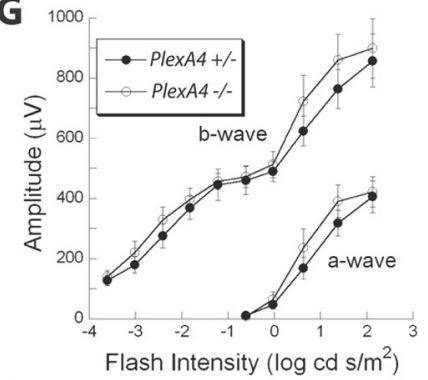

I

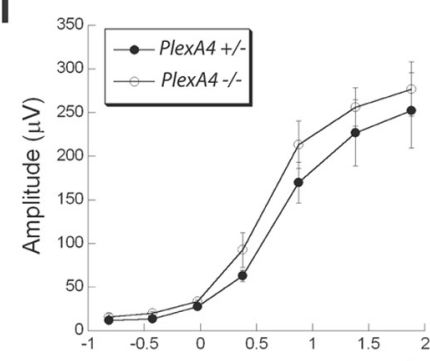

Flash Intensity $\left(\log \mathrm{cd} \mathrm{s} / \mathrm{m}^{2}\right)$
Figure 5. PlexinA4 directs horizontal cell axon apposition within rod ribbon synapses, but PlexA4 ${ }^{-1-}$ retinas exhibit normal dark-adapted and light-adapted ERG responses. $\boldsymbol{A}-\boldsymbol{D}$, EM analysis of rod ribbon synapses reveals synaptic ultrastructure in WT $(\boldsymbol{A}$, $\boldsymbol{B})$ and PlexA4 ${ }^{-\prime-}(\boldsymbol{C}, \boldsymbol{D})$ adult retinas. In WT retinas, rod ribbon synapses are in most cases surrounded by two horizontal cell neurites $(\boldsymbol{A}, \boldsymbol{B})$; however, in PlexA4 ${ }^{-/-}$retinas, a significantly increased number of rod ribbon synapses lack one horizontal cell neurite $(\boldsymbol{C}, \boldsymbol{D})$. H, Horizontal cell neurite tips; B, bipolar cell dendritic tips. $\boldsymbol{E}$, Quantification of ribbon synapses associated with one or no horizontal cell neurite (defined here as a "nonsurrounded ribbon"); $7.3 \pm 1.7 \%$ for WT retinas and $26.2 \pm 4.3 \%$ for PlexA4 ${ }^{-/-}$retinas. The number of rod ribbon synapses quantified is 233 for WT and 234 for PlexA4 ${ }^{-1-}$ retinas $(n=3$ retinas from three animals for each genotype). $p=0.015$ by Student's $t$ test. $\boldsymbol{F}-\boldsymbol{I}$, Representative dark-adapted ERGs $(\boldsymbol{F})$ and lightadapted ERGs $(\boldsymbol{H})$ obtained from PlexA4 ${ }^{+/-}$and PlexA4 ${ }^{-/-}$mice. Intensity response functions for the amplitude of the a-wave and b-wave of dark-adapted ERGs $(\boldsymbol{G})$ and light-adapted ERGs $(\boldsymbol{I})$ obtained from PlexA4 ${ }^{+/-}$and PlexA4 ${ }^{-\prime-}$ mice. The amplitudes of the a-wave and the b-wave of dark-adapted ERGs $(\boldsymbol{G})$ as well as light-adapted ERGs $(\boldsymbol{I})$ are comparable between $\mathrm{PI}$ exA4 $4^{+/-}$and PlexA4 ${ }^{-\prime-}$ mice. Data points indicate average \pm SEM for four or more mice. Scale bar: (in $\left.\boldsymbol{D}\right) \boldsymbol{A}-\boldsymbol{D}, 500 \mathrm{~nm}$.

\section{PlexA4 directs horizontal cell axon apposition within rod ribbon synapses}

At the ultrastructural level, electron microscopy (EM) reveals abnormal rod ribbon synapse structure in the PlexA4 ${ }^{-/-}$retina (Fig. 5A-E). In WT retinas, the majority of rod ribbon synapses contain the tips of two horizontal cell neurites surrounding a rod synaptic ribbon (Fig. $5 A, B$ ). In contrast, Plex $A 4^{-/-}$retinas ex- 


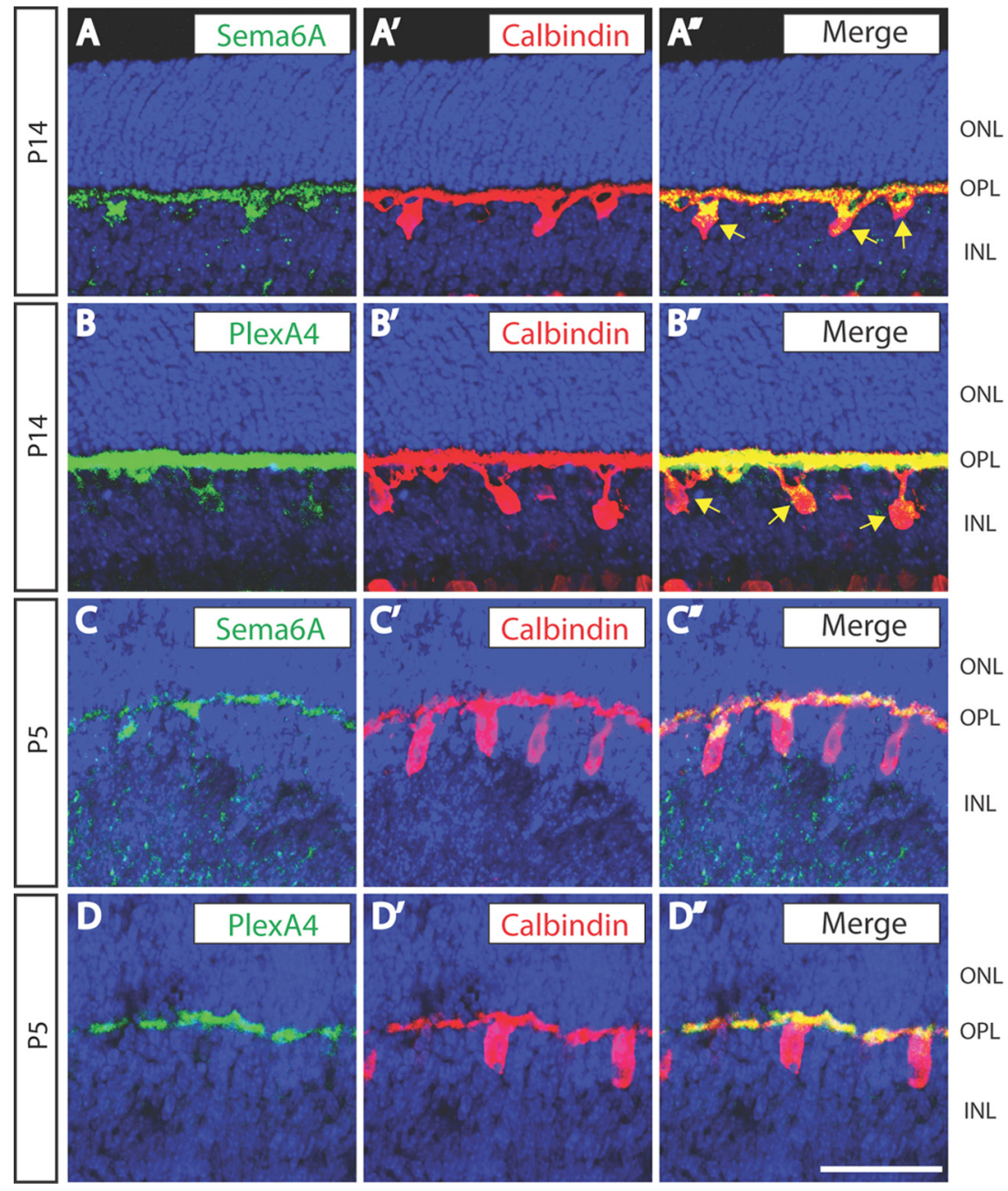

Figure 6. Sema6A and PlexinA4 are both localized in horizontal cell bodies and neurites. $\boldsymbol{A}-\boldsymbol{D}^{\prime \prime}$, WT retina sections from P14 $\left(\boldsymbol{A}-\boldsymbol{B}^{\prime \prime}\right)$ and P5 $\left(\boldsymbol{C}-\boldsymbol{D}^{\prime \prime}\right)$ mice were double immunostained with anti-calbindin $\left(\boldsymbol{A}^{\prime}, \boldsymbol{B}^{\prime}, \boldsymbol{C}^{\prime}, \boldsymbol{D}^{\prime}\right.$, red $)$ and either anti-Sema6A $(\boldsymbol{A}, \boldsymbol{C}$, green) or anti-PlexA4 (B, $\boldsymbol{D}$, green). Both Sema6A and PlexA4 are localized to horizontal cell bodies (yellow arrows) and neurites within the OPL $\left(\boldsymbol{A}^{\prime \prime}, \boldsymbol{B}^{\prime \prime}, \boldsymbol{C}^{\prime \prime}, \boldsymbol{D}^{\prime \prime}\right)$. Scale bar, $50 \mu \mathrm{m}$.

hibit over a threefold increase in the number of rod ribbon synapses harboring only one horizontal cell process [Fig. 5C-E; quantification of non-HC-surrounded rod ribbons: $7.3 \pm 1.7 \%$ for WT retinas (of 233 rod ribbon synapses) and $26.2 \pm 4.3 \%$ for PlexA $4^{-/-}$retinas (of 234 rod ribbon synapses); $n=3$ retinas for each genotype]. This finding that some, but not all, horizontal cell axons fail to invade rod synaptic terminals in PlexA4 ${ }^{-/-}$ retinas is commensurate with our observation that not all PlexA $4^{-/-}$horizontal cells exhibit neurite mistargeting into the ONL. PlexA4 $4^{-/-}$retinas exhibit normal ERGs under both darkadapted and light-adapted conditions (Fig. $5 F-I$ ), indicating that synaptic function between photoreceptors and bipolar cell dendrites is largely intact in PlexA $4^{-/-}$retinas; this is consistent with the normal stratification of photoreceptor axons and bipolar cell dendrites we observe in PlexA4 ${ }^{-/-}$retinas (Fig. 4).

Sema6A and PlexA4 are localized to horizontal cell bodies and neurites, and Sema6A-PlexA4 signaling governs horizontal cell dendritic arborization and self-avoidance

To understand how Sema6A and PlexA4 regulate horizontal cell development, we performed protein expression analysis using antibodies against these proteins (Matsuoka et al., 2011a). Both
Sema6A and PlexA4 are localized in horizontal cell neurites and cell bodies in the developing OPL (Fig. 6)

Since repulsive interactions mediated by Sema6A and PlexA4 could serve to regulate the mosaic patterning of horizontal cells (Raven et al., 2005; Suto et al., 2005, 2007), we examined horizontal cell neurites and cell bodies in the tangential plane at the level of the OPL. Markedly fewer horizontal cell neurites occupy the OPL in PlexA4 ${ }^{-1-}$ retinas at P5 (Fig. $7 A-C$ ); however, the number of horizontal cell bodies and their mosaic spacing are the same as in P5 WT retinas (Fig. 7D-G). Sema6 ${ }^{-1-}$ P5 retinas phenocopy these defects in horizontal cell neurite targeting and neurite coverage within the OPL observed in PlexA4 ${ }^{-/-}$mutants (Fig. $8)$. To better assess horizontal cell neurite arborization in PlexA4 $4^{-/-}$retinas, we filled individual horizontal cells with Alexa fluorescent 555 dye (Fig. 9A,B). PlexA $4^{-/-}$adult horizontal cells do not show a significant difference in overall neurite length compared with WT horizontal cells (Fig. 9C). However, Plex $A 4^{-1-}$ horizontal cells display an aberrant dendritic field organization that results in reduced dendritic process self-avoidance, compared with WT adult horizontal cells (Fig. 9A-B",D). Together with our observation that Sema6A and PlexinA4 are colocalized in horizontal cells during postnatal development (Fig. 6), this finding suggests that repulsive signaling between Sema6A and PlexinA4 is required for isoneuronal dendritic self-avoidance in horizontal cells.

\section{Discussion}

Our results show that transmembrane semaphorin-plexin signaling directs horizontal cell axon targeting, dendritic process self-avoidance, and the correct localization of horizontal cell neurites along rod ribbon synapses within the OPL of the mammalian retina. Intriguingly, aberrant horizontal cell axon projections into the ONL are not accompanied by mistargeting of photoreceptor axons or bipolar cell dendrites, indicating that normal stratification of photoreceptor axons and bipolar cell dendrites within the OPL is not sufficient for constraining horizontal cell axons to ribbon synapses within the OPL. These results also suggest that horizontal cell neurite stratification within the OPL in part relies on cues that do not come from photoreceptors and bipolar cells. Indeed, Sema6A and PlexinA4 are localized in horizontal cells and are required for proper horizontal cell neurite stratification within the OPL. Therefore, in addition to the previously characterized roles played by neurotransmission, classical guidance cue signaling also contributes to mammalian outer retinal lamination.

The mouse retina has a single type of horizontal cell that elaborates axons (Peichl and González-Soriano, 1993, 1994), and these horizontal cell axons synapse with rod photoreceptor axon terminals, in contrast to horizontal cell dendrites, which form synapses with cone photoreceptors and form gap junctions with 
neighboring horizontal cells (Reese et al., 2005). We find that many horizontal cell axons are mistargeted to the ONL of PlexA4 $4^{-1-}$ and Sema6A ${ }^{-1-}$ retinas, resulting in an increased number of rod ribbon synapses that lack the normal complement of horizontal cell axons. Further, horizontal cell dendritic arborization in the OPL is compromised in these mutant retinas. Defects in horizontal cell dendritic process self-avoidance in PlexA4 ${ }^{-/-}$and Sema6 $A^{-/-}$retinas result in abnormal dendrite elaboration, and these phenotypes likely affect the formation of appropriate connections with neighboring horizontal cell dendrites and/or cone photoreceptor axon terminals. The horizontal cell selfavoidance defect we observe is unique in that it is not accompanied by alterations in horizontal cell mosaic cell body spacing, as is observed in DSCAM mutants (Fuerst et al., 2008, 2009, 2012).

Horizontal cell axons and dendrites choose distinct photoreceptors (rods and cones, respectively) as synaptic partners (Raven et al., 2007). Both horizontal cell axonal targeting and dendritic arborization require Sema6A-PlexA4 signaling; however, Sema6A-PlexA4 signaling could control these two events through distinct mechanisms. Horizontal cell axons typically extend over long distances, and their axonal terminals are highly elaborated so as to synapse with many rod photoreceptors residing far from their cell bodies (Peichl and González-Soriano, 1994; Raven et al., 2007). However, horizontal cell dendritic processes cover OPL regions so as to connect with cone photoreceptors that are more closely associated with their cell bodies (Peichl and González-Soriano, 1994; Raven et al., 2007). One possible mechanism underlying isoneuronal tiling of horizontal cell dendritic processes is that Sema6A and PlexA4 within the same horizontal cell mediate cell-autonomous repulsive interactions to establish complete coverage of the OPL by their dendrites. On the other hand, horizontal cell axon targeting may be constrained within the OPL by non-cell autonomous cues (Sema6A and/or PlexA4) presented by other horizontal cells, perhaps acting through adhesive mechanisms, to ensure that horizontal cell axons correctly target rod ribbon synapses. Selectively removing Sema6A and/or PlexA4 gene expression in horizontal cells, combined with select labeling of horizontal cells, will begin to address these issues.

Sema6A-PlexA4 signaling within horizontal cells governs the developmental program that controls horizontal cell neurite morphology and targeting, thereby organizing outer retina lamination and ribbon synapse formation. A recent study identified pikachurin as a critical regulator of bipolar cell dendrite apposition within rod ribbon synapses (Sato et al., 2008); however, horizontal cell axon contributions to rod ribbon synapses are intact in Pikachurin mutants (Sato et al., 2008). We show here that horizontal cell axon contributions to rod ribbon synapses require Sema6A-PlexA4 signaling; however, Sema6A-PlexA4 signaling is not apparently required for bipolar cell dendrite apposition within ribbon synapses. It will be of interest to determine whether additional guidance cues and their receptors also regulate outer retina development, and also how retinal development and function are affected when these signaling events are compromised.

\section{References}

Blanks JC, Adinolfi AM, Lolley RN (1974) Synaptogenesis in the photoreceptor terminal of the mouse retina. J Comp Neurol 156:81-93.

Budzynski E, Gross AK, McAlear SD, Peachey NS, Shukla M, He F, Edwards M, Won J, Hicks WL, Wensel TG, Naggert JK, Nishina PM (2010) Mutations of the opsin gene ( $\mathrm{Y} 102 \mathrm{H}$ and $\mathrm{I} 307 \mathrm{~N})$ lead to light-induced degeneration of photoreceptors and constitutive activation of phototransduction in mice. J Biol Chem 285:14521-14533.

Chang B, Heckenlively JR, Bayley PR, Brecha NC, Davisson MT, Hawes NL, Hirano AA, Hurd RE, Ikeda A, Johnson BA, McCall MA, Morgans CW, Nusinowitz S, Peachey NS, Rice DS, Vessey KA, Gregg RG (2006) The nob2 mouse, a null mutation in Cacnalf: anatomical and functional ab- 


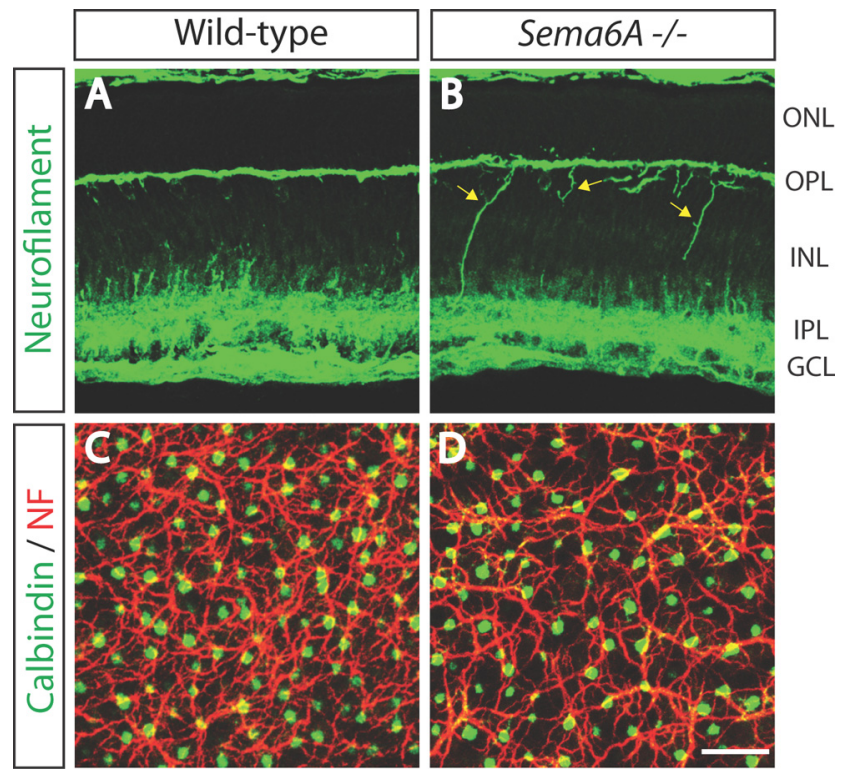

Figure 8. Sema6 $A^{-1-}$ retinas phenocopy the early postnatal horizontal cell neurite arborization defects observed in PlexA $4^{-1-}$ retinas. $\boldsymbol{A}, \boldsymbol{B}, \mathrm{P} 5 \mathrm{WT}(\boldsymbol{A})$ and Sema6A $A^{-1-}(\boldsymbol{B})$ retina sections were immunostained with anti-neurofilament. Horizontal cells in Sema6 $A^{-1-}$ retinas exhibit aberrant neurites within the INL (yellow arrows), as we observed in PlexA4 ${ }^{-1-}$ retinas during early postnatal retinal development. C, D, P5 WT (C) and Sema6A ${ }^{-\prime-}$ (D) whole-mount retinas were double immunostained with anti-calbindin (green) and antineurofilament (NF, red). As observed in PlexA4 ${ }^{-1-}$ retinas, Sema6 $\mathrm{A}^{-1-}$ retinas exhibitfewer horizontal cell neurites covering the surface of the OPL compared with WT retinas. Scale bar, $50 \mu \mathrm{m}$.

normalities in the outer retina and their consequences on ganglion cell visual responses. Vis Neurosci 23:11-24.

Claes E, Seeliger M, Michalakis S, Biel M, Humphries P, Haverkamp S (2004) Morphological characterization of the retina of the CNGA3(-/ $-) \mathrm{Rho}(-/-)$ mutant mouse lacking functional cones and rods. Invest Ophthalmol Vis Sci 45:2039-2048.

Dhingra A, Lyubarsky A, Jiang M, Pugh EN Jr, Birnbaumer L, Sterling P, Vardi N (2000) The light response of ON bipolar neurons requires G $[\alpha]$ o. J Neurosci 20:9053-9058.

Dick O, tom Dieck S, Altrock WD, Ammermüller J, Weiler R, Garner CC, Gundelfinger ED, Brandstätter JH (2003) The presynaptic active zone protein bassoon is essential for photoreceptor ribbon synapse formation in the retina. Neuron 37:775-786.

Fuerst PG, Koizumi A, Masland RH, Burgess RW (2008) Neurite arborization and mosaic spacing in the mouse retina require DSCAM. Nature 451:470-474.

Fuerst PG, Bruce F, Tian M, Wei W, Elstrott J, Feller MB, Erskine L, Singer JH, Burgess RW (2009) DSCAM and DSCAML1 function in selfavoidance in multiple cell types in the developing mouse retina. Neuron 64:484-497.

Fuerst PG, Bruce F, Rounds RP, Erskine L, Burgess RW (2012) Cell autonomy of DSCAM function in retinal development. Dev Biol 361:326-337.

Giger RJ, Cloutier JF, Sahay A, Prinjha RK, Levengood DV, Moore SE, Pickering S, Simmons D, Rastan S, Walsh FS, Kolodkin AL, Ginty DD, Geppert M (2000) Neuropilin-2 is required in vivo for selective axon guidance responses to secreted semaphorins. Neuron 25:29-41.

Gu C, Rodriguez ER, Reimert DV, Shu T, Fritzsch B, Richards LJ, Kolodkin AL, Ginty DD (2003) Neuropilin-1 conveys semaphorin and VEGF signaling during neural and cardiovascular development. Dev Cell 5:45-57.

Haeseleer F, Sokal I, Verlinde CL, Erdjument-Bromage H, Tempst P, Pronin AN, Benovic JL, Fariss RN, Palczewski K (2000) Five members of a novel $\mathrm{Ca}(2+)$-binding protein (CABP) subfamily with similarity to calmodulin. J Biol Chem 275:1247-1260.

Haeseleer F, Imanishi Y, Maeda T, Possin DE, Maeda A, Lee A, Rieke F, Palczewski K (2004) Essential role of Ca2+-binding protein 4, a Cav1.4 channel regulator, in photoreceptor synaptic function. Nat Neurosci 7:1079-1087.
Haverkamp S, Wässle H (2000) Immunocytochemical analysis of the mouse retina. J Comp Neurol 424:1-23.

Huckfeldt RM, Schubert T, Morgan JL, Godinho L, Di Cristo G, Huang ZJ, Wong RO (2009) Transient neurites of retinal horizontal cells exhibit columnar tiling via homotypic interactions. Nat Neurosci 12:35-43.

Lee EJ, Padilla M, Merwine DK, Grzywacz NM (2008) Developmental regulation of the morphology of mouse retinal horizontal cells by visual experience. Eur J Neurosci 27:1423-1431.

Leighton PA, Mitchell KJ, Goodrich LV, Lu X, Pinson K, Scherz P, Skarnes WC, Tessier-Lavigne M (2001) Defining brain wiring patterns and mechanisms through gene trapping in mice. Nature 410:174-179.

Leslie JR, Imai F, Fukuhara K, Takegahara N, Rizvi TA, Friedel RH, Wang F, Kumanogoh A, Yoshida Y (2011) Ectopic myelinating oligodendrocytes in the dorsal spinal cord as a consequence of altered semaphorin 6D signaling inhibit synapse formation. Development 138:4085-4095.

Liets LC, Eliasieh K, van der List DA, Chalupa LM (2006) Dendrites of rod bipolar cells sprout in normal aging retina. Proc Natl Acad Sci U S A 103:12156-12160.

Masland RH (2001) The fundamental plan of the retina. Nat Neurosci 4:877-886.

Masu M, Iwakabe H, Tagawa Y, Miyoshi T, Yamashita M, Fukuda Y, Sasaki H, Hiroi K, Nakamura Y, Shigemoto R (1995) Specific deficit of the ON response in visual transmission by targeted disruption of the mGluR6 gene. Cell 80:757-765.

Matsuoka RL, Nguyen-Ba-Charvet KT, Parray A, Badea TC, Chédotal A, Kolodkin AL (2011a) Transmembrane semaphorin signalling controls laminar stratification in the mammalian retina. Nature 470:259-263.

Matsuoka RL, Chivatakarn O, Badea TC, Samuels IS, Cahill H, Katayama K, Kumar SR, Suto F, Chédotal A, Peachey NS, Nathans J, Yoshida Y, Giger RJ, Kolodkin AL (2011b) Class 5 transmembrane semaphorins control selective Mammalian retinal lamination and function. Neuron 71:460-473.

Mumm JS, Godinho L, Morgan JL, Oakley DM, Schroeter EH, Wong RO (2005) Laminar circuit formation in the vertebrate retina. Prog Brain Res 147:155-169.

Peichl L, González-Soriano J (1993) Unexpected presence of neurofilaments in axon-bearing horizontal cells of the mammalian retina. J Neurosci 13:4091-4100.

Peichl L, González-Soriano J (1994) Morphological types of horizontal cell in rodent retinae: a comparison of rat, mouse, gerbil, and guinea pig. Vis Neurosci 11:501-517.

Pinto LH, Vitaterna MH, Shimomura K, Siepka SM, Balannik V, McDearmon EL, Omura C, Lumayag S, Invergo BM, Glawe B, Cantrell DR, Inayat S, Olvera MA, Vessey KA, McCall MA, Maddox D, Morgans CW, Young B, Pletcher MT, Mullins RF, et al (2007) Generation, identification and functional characterization of the nob4 mutation of Grm6 in the mouse. Vis Neurosci 24:111-123.

Raven MA, Stagg SB, Reese BE (2005) Regularity and packing of the horizontal cell mosaic in different strains of mice. Vis Neurosci 22:461-468.

Raven MA, Oh EC, Swaroop A, Reese BE (2007) Afferent control of horizontal cell morphology revealed by genetic respecification of rods and cones. J Neurosci 27:3540-3547.

Reese BE, Raven MA, Stagg SB (2005) Afferents and homotypic neighbors regulate horizontal cell morphology, connectivity, and retinal coverage. J Neurosci 25:2167-2175.

Renaud J, Kerjan G, Sumita I, Zagar Y, Georget V, Kim D, Fouquet C, Suda K, Sanbo M, Suto F, Ackerman SL, Mitchell KJ, Fujisawa H, Chédotal A (2008) Plexin-A2 and its ligand, Sema6A, control nucleus-centrosome coupling in migrating granule cells. Nat Neurosci 11:440-449.

Rockhill RL, Euler T, Masland RH (2000) Spatial order within but not between types of retinal neurons. Proc Natl Acad Sci U S A 97:2303-2307.

Rodieck RW (1991) The density recovery profile: a method for the analysis of points in the plane applicable to retinal studies. Vis Neurosci 6:95-111.

Rünker AE, Little GE, Suto F, Fujisawa H, Mitchell KJ (2008) Semaphorin-6A controls guidance of corticospinal tract axons at multiple choice points. Neural Dev 3:34.

Samuel MA, Zhang Y, Meister M, Sanes JR (2011) Age-related alterations in neurons of the mouse retina. J Neurosci 31:16033-16044.

Sato S, Omori Y, Katoh K, Kondo M, Kanagawa M, Miyata K, Funabiki K, Koyasu T, Kajimura N, Miyoshi T, Sawai H, Kobayashi K, Tani A, Toda T, Usukura J, Tano Y, Fujikado T, Furukawa T (2008) Pikachurin, a dys- 
troglycan ligand, is essential for photoreceptor ribbon synapse formation. Nat Neurosci 11:923-931.

Specht D, Tom Dieck S, Ammermüller J, RegusLeidig $\mathrm{H}$, Gundelfinger ED, Brandstätter JH (2007) Structural and functional remodeling in the retina of a mouse with a photoreceptor synaptopathy: plasticity in the rod and degeneration in the cone system. Eur J Neurosci 26:2506-2515.

Strettoi E, Porciatti V, Falsini B, Pignatelli V, Rossi C (2002) Morphological and functional abnormalities in the inner retina of the $\mathrm{rd} / \mathrm{rd}$ mouse. J Neurosci 22:5492-5504.

Strettoi E, Pignatelli V, Rossi C, Porciatti V, Falsini B (2003) Remodeling of secondorder neurons in the retina of $\mathrm{rd} / \mathrm{rd}$ mutant mice. Vision Res 43:867-877.

Suto F, Ito K, Uemura M, Shimizu M, Shinkawa Y, Sanbo M, Shinoda T, Tsuboi M, Takashima S, Yagi T, Fujisawa H (2005) Plexin-a4 mediates axon-repulsive activities of both secreted and transmembrane semaphorins and plays roles in nerve fiber guidance. J Neurosci 25:3628-3637.

Suto F, Tsuboi M, Kamiya H, Mizuno H, Kiyama Y, Komai S, Shimizu M, Sanbo M, Yagi T, Hiromi Y, Chédotal A, Mitchell KJ, Manabe T, Fujisawa H (2007) Interactions between plexin-A2, plexin-A4, and semaphorin $6 \mathrm{~A}$ control lamina-restricted projection of hippocampal mossy fibers. Neuron 53:535-547.

Tagawa Y, Sawai H, Ueda Y, Tauchi M, Nakanishi S (1999) Immunohistological studies of metabotropic glutamate receptor subtype 6-deficient mice show no abnormality of retinal cell organization and ganglion cell maturation. J Neurosci 19:2568-2579.

Tawarayama H, Yoshida Y, Suto F, Mitchell KJ, Fujisawa H (2010) Roles of semaphorin-6B and plexin-A2 in lamina-restricted projection of hippocampal mossy fibers. J Neurosci 30:7049-7060.

Wässle H (2004) Parallel processing in the mammalian retina. Nat Rev Neurosci 5: 747-757.

Wearne SL, Rodriguez A, Ehlenberger DB, Rocher AB, Henderson SC, Hof PR (2005) New techniques for imaging, digitization and analysis of three-dimensional neural morphology on multiple scales. Neuroscience 136:661-680.

Wycisk KA, Budde B, Feil S, Skosyrski S, Buzzi F, Neidhardt J, Glaus E, Nürnberg P, Ruether K, Berger W (2006) Structural and functional ab-
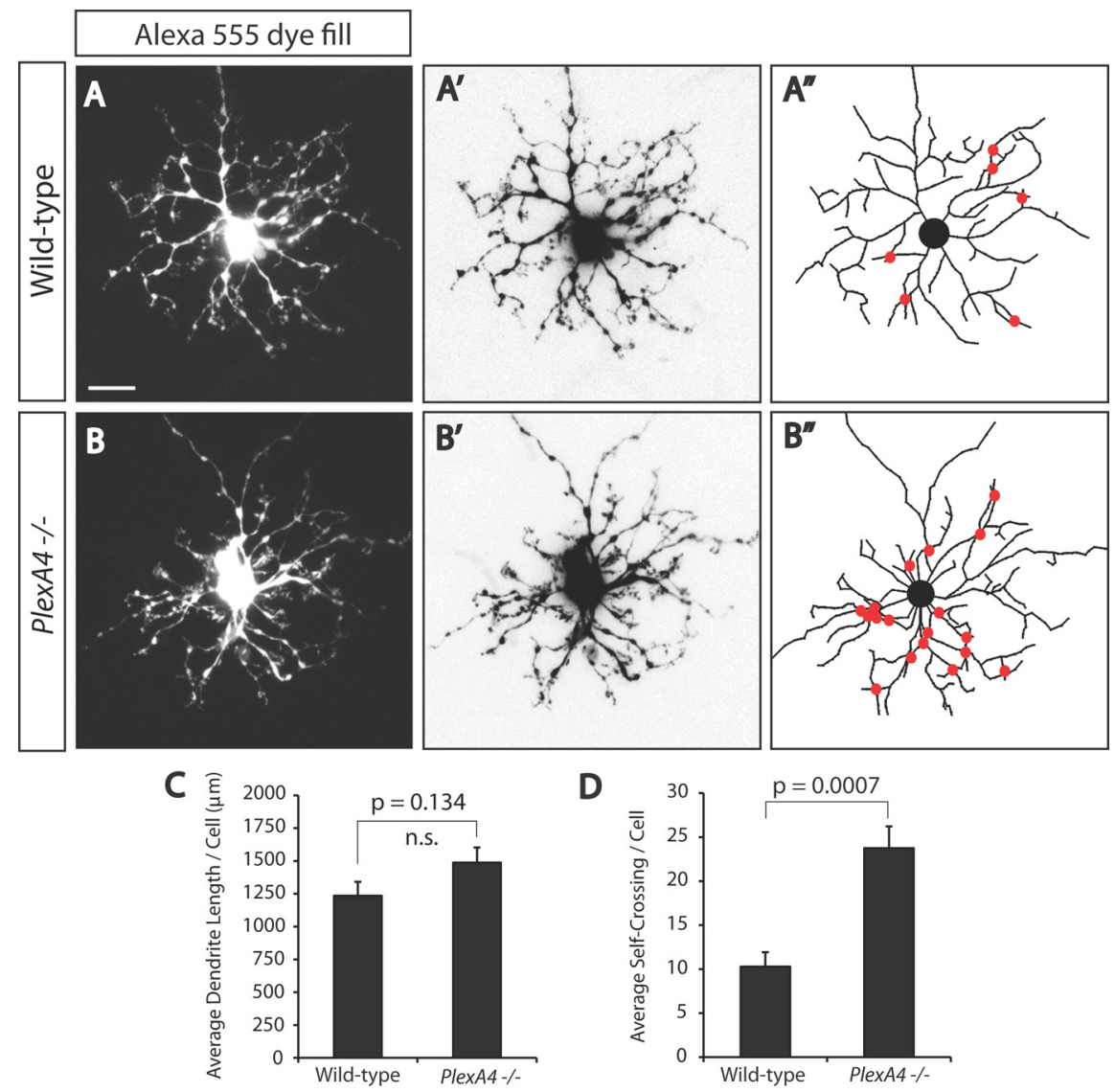

Figure 9. PlexA4 $4^{-1-}$ horizontal cells exhibit reduced dendritic self-avoidance in vivo. $A, B$, Representative images of WT (A) and PlexA4 $4^{-\prime-}(\boldsymbol{B})$ adult horizontal cells filled with Alexa Fluor 555 fluorescence dye. $\boldsymbol{A}^{\prime}, \boldsymbol{A}^{\prime \prime}, \boldsymbol{B}^{\prime}, \boldsymbol{B}^{\prime \prime}$, Representative inverted images of WT $\left(\boldsymbol{A}^{\prime}\right)$ and Plex $A 4^{-{ }^{--}}\left(\boldsymbol{B}^{\prime}\right)$ adult horizontal cells filled with Alexa Fluor 555 fluorescence dye. Horizontal cell neurites from these images were traced in $\boldsymbol{A}^{\prime \prime}$ and $\boldsymbol{B}^{\prime \prime}$. Red dots indicate sites where neurites cross. $C$, Quantification of average horizontal cell neurite length per neuron of WT and PlexA4 ${ }^{-1-}$ adult horizontal cells. The average horizontal cell neurite lengths per cell are $1238 \pm 107 \mu \mathrm{m}$ for WT $(n=7)$ and $1492 \pm 115 \mu \mathrm{m}$ for PlexA4 ${ }^{-/-}(n=8)$ horizontal cells. $p=0.134$, Student's $t$ test. $\boldsymbol{D}$, Quantification of the average number of self-neurite crossings in WT and PlexA4 ${ }^{-/-}$adult horizontal cells. The average number of crossings per cell are $10.3 \pm 1.6$ for WT $(n=7)$ and $23.8 \pm 2.5$ for PlexA4 ${ }^{-1-}(n=8)$ horizontal cells. $p=0.0007$, Student's $t$ test. Scale bar: (in $\boldsymbol{A}$ ) for $\boldsymbol{A}-\boldsymbol{B}^{\prime \prime}, 20 \mu \mathrm{m}$.

normalities of retinal ribbon synapses due to Cacna2d4 mutation. Invest Ophthalmol Vis Sci 47:3523-3530.

Yaron A, Huang PH, Cheng HJ, Tessier-Lavigne M (2005) Differential requirement for Plexin-A3 and -A4 in mediating responses of sensory and sympathetic neurons to distinct class 3 Semaphorins. Neuron 45:513523. 